\title{
PENERAPAN AKUNTANSI LINGKUNGAN PADA BADAN USAHA MILIK DESA UNTUK MEWUJUDKAN GREEN ACCOUNTING (STUDI KASUS PADA BADAN USAHA MILIK DESA " $X ")$
}

\author{
Rizky Wulandari \\ Program Studi Akuntansi, Departemen Ekonomika dan Bisnis, Sekolah Vokasi, UGM \\ Email: rizky wulandari@ugm.ac.id \\ Dina Natasari \\ Program Studi Akuntansi, Departemen Ekonomika dan Bisnis, Sekolah Vokasi, UGM \\ Email: dina.natasari@ugm.ac.id \\ Ihda Arifin Faiz \\ Program Studi Akuntansi, Departemen Ekonomika dan Bisnis, Sekolah Vokasi, UGM \\ Email: ihda@ugm.ac.id
}

\begin{abstract}
Village Owned Enterprises (BUMDes) is one of the village entities which foundation aims to improve village welfare through the optimization of village resources. BUMDes in its operations is expected to show social responsibility to the community. One of the social responsibilities is to apply environmental accounting. Environmental accounting means that accounting asa source ofmanagement's responsibility information to stakeholders which also provide information about the impact of business processes entityto the surroundingenvironment. Information onthe environmental impacts disclosed in thefinancial statements which arereferred to asGreen Accounting. This research aims to analyze the application of environmental accounting on BUMDes " $\mathrm{X}$ " in relation to the realization of Green Accounting. Analysis of the application of environmental accounting to benchmark whether the Green Accounting entity is realized or not.

This research is a qualitative descriptive study. The analysis was conducted by conducting in-depth interviews with the relevant parties as well as observing the environmental accounting, analyzing the BUMDes financial statements, and documenting the results. Data obtained through interviews, observation, and documentation. The data that has been obtained is then documented and drawn conclusions. The results showed that in accordance with PSAK 1 concerning the presentation of financial reporting, BUMDes " $X$ " has compiled reports relating to environmental impacts. Although the report is still simple, the separate presentation of this environmental accounting report has shown concern for BUMDes " $X$ " in providing information related to environmental accounting. Optimization of the application of environmental accounting ultimately depends on the policy, human resources, and infrastructure readiness of the implementing entity.
\end{abstract}

Keywords: environmental accounting, green accounting, environmental costs, financial statement, social responsibility 


\section{PENDAHULUAN}

Perkembangan kewenangan daerah dengan adanya otonomi daerah mengubah kewenanganpemerintah dalam memanfaatkan aset daerah. Cepatnya tingkat pembangunan di masing-masing daerah dengan adanya otonomi ini terkadang mengesampingkan aspek lingkungan yang disadari atau tidak pada akhirnya akan menjadi penyebab utama terjadinya permasalahan lingkungan. Tanpa kontrol yang kuat dari pemerintah pusat atau provinsi, potensi kerusakan lingkungan akan semakin besar. Kebijakan pemerintah untuk memberikan dana desa dalam nilai yang cukup besar berpotensi melonjaknya pembangunan di berbagai desa. Tujuan dibentuknya Badan Usaha Milik Desa (BUMDes) adalah sebagai sebuah badan yang berada di desa, menyediakan jasa dan atau produk yang dapat dipergunakan oleh warga desa untuk memenuhi kebutuhan hidupnya.Badan ini dituntut menjalankan fungsi ekonomi dan sosial.Tuntutan tersebut membawa konsekuensi bahwa posisi desa mempunyai peran penting dalam mengelola sumber daya desa sebagai usaha untuk menghasilkan aspek ekonomi dengan tetap memperhatikan aspek sosial melalui BUMDes.Peningkatan aspek ekonomi melalui unit usaha desa ini secara tidak langsung akan membawa konsekuensi dampak sosial. Pemanfaatan aset untuk disewakan, menjadi obyek wisata, atau pemberdayaan masyarakat untuk membentuk industri-industri rumahan yang dikoordinasikan di tingkat desa akan menimbulkan permasalahan lingkungan. Sebagai contoh dampak lingkungan yang ditimbulkan adalah adanya permasalahan limbah, polusi dan berkurangnya lahan terbuka hijau.Hal ini menjadi tantangan bagi desa untuk dapat menjalankan fungsi ekonomi tersebut dengan tetap memperhatikan aspek lingkungan.Potensi pembangunan tersebut juga membawa potensi risiko pada timbulnya permasalahan lingkungan.

Konsep Green accounting merupakan kerangka akuntansi yang melibatkan pendekatan pelaporan meliputi 3 (tiga) aspek yaitu pelaporan terkait dengan sosial, pelaporan terkait dengan lingkungan dan pelaporan terkait dengan keuangan (Kusumaningtyas, 2013). Dengan menerapkan konsep green accounting maka diharapkan pelaporan suatu perusahaan dapat lebih bersifat menyeluruh baik aspek keuangan maupun non keuangan. MenurutEnvironmental 
Accounting Guidelines (2012), akuntansi lingkungan mencangkup beberapa tahapan proses yaitu pertama, proses identifikasi biaya dan manfaat dari aktivitas lingkungan, kedua ketersediaan sarana pendukung untuk menjaga keberlanjutan proses, ketiga menjalin hubungan antar aspek yang terlibat, dan terakhir memperoleh hasil dan menguji efektivitas dari kegiatan tersebut. Berdasarkan hal tersebut, penelitian ini akan menganalisis penerapan akuntansi lingkungan pada BUMDes " $\mathrm{X}$ ” sebagai konsekuensi tujuan dibentuknya BUMDes yaitu mempertimbangkan aspek keuangan dan non keuangan (faktor sosial dan lingkungan).BUMDes " $\mathrm{X}$ ” bergerak dalam usaha simpan pinjam, perdagangan hasil masyarakat, persewaan mesin, jasa fotokopi dan pengelolaan sampah.

\section{a. Tujuan dan Manfaat}

\section{Tujuan}

Penelitian ini akan menganalisis penerapan akuntansi lingkungan dalam rangka mewujudkan green accounting dengan pendekatan studi kasus pada BUMDes "X". Tujuan penelitian ini akan melihat penerapan kebijakan pemerintah desa dalam mengatasi potensi permasalahan dampak lingkungan ditinjau dari penerapan konsep akuntansi lingkungan yang merupakan wujud pertanggungjawaban pengelola kepada masyarakatnya baik dari aspek keuangan dan non keuangan dan kendala-kendala yang muncul selama proses penerapan akuntansi lingkungan pada BUMDes "X". Penelitian ini diharapkan akan memberikan manfaat baik secara akademis maupun praktis untuk kalangan peneliti, dan pemangku kepentingan.

\section{Manfaat}

Adapun manfaat dari penelitian ini adalah Mengetahui penerapan green accounting khususnya pada pemerintah desa, Pengembangan konsep penerapan green accounting bagi rumpun ilmu akuntansi, Sebagai bahan pertimbangan bagi pengambil keputusan dalam rangka pertanggungjawaban kepada stake holder, Pergeseran kebijakan akuntansi pada penyajian dan pengungkapan dengan mempertimbangkan aspek non keuangan (sosial dan lingkungan).

\section{b. Identifikasi masalah}

Penelitian ini menganalisis penerapan akuntansi lingkungan dengan pendekatan studi kasus pada BUM Desa yang terdapat di Desa " $X$ " dalam mewujudkan green accounting. Pertimbangan pemilihan 
pendekatan studi kasus ini adalah untuk melihat sejauh mana konsep akuntansi lingkungan dapat diterapkan di BUMDes "X". Sedangkan pemilihan obyek penelitian di sini dikarenakan desa tersebut sedang berkembang di sektor industri dan pariwisata.Perkembangan ini membawa potensi risiko pada pemanfaatan aset desa dan permasalahan lingkungan seperti limbah, sampah, pencemaran dan dampak lingkungan lainnya.Selain itu, BUMDes "X" saat ini sedang dalam pengembangan aktivitas pengolahan limbah.Penelitian ini pada awalnya melihat kebijakan pemerintah desa dalam mengatasi potensi permasalahan tersebut ditinjau dari penerapan konsep akuntansi lingkungan yang merupakan wujud pertanggungjawaban pengelola kepada masyarakatnya baik dari aspek keuangan dan non keuanganuntuk mewujudkan green accounting. Selain itu penelitian ini juga mengidentifikasi kendala-kendala yang muncul dalam penerapannya.

\section{c. Dasar teori}

Konsep Akuntansi Lingkungan, Akuntansi Sosial dan Green Accounting

Pengertian Akuntansi lingkungan menurut United States Environment Protection Agency (US-EPA), "Green
Accounting is identifying and measuring the cost of environmental materials and activities and using this information for environmental management decisions. The purpose is to recognize and seek to mitigate the negative environmental effects of activities and sistems" (Memorandum USEPA, 1995: 20).Dipaparkan pula USEPA Dijelaskan pula, US-EPA membagi istilah akuntansi lingkungan menjadi dua hal utama yaitu bahwa akuntansi lingkungan merupakan sebuah biaya yang mempengaruhi secara langsung bagi perusahaan secara keseluruhan.Kedua, akuntansi lingkungan merupakan biaya individu, masyarakat maupun lingkungan suatu perusahaan yang tidak berdampak langsung pada perusahaan dan tidak dapat dipertanggungjawabkan oeh perusahaan.

Menurut International Guidance Document: Environmental Management Accounting (2005), Akuntansi Lingkungan adalah merupakan sebuah istilah yang berarti luas yang dapat digunakan pada berbagai konteks, antara lain:

1. penilaian dan pengungkapan informasi keuangan, dalam hal ini akuntansi lingkungan dipandang dari konteks pertanggungjawaban akuntansi, pelaporan keuangan; 
2. penilaian dan penggunaan informasi fisik dan moneter terkait lingkungan di konteks Environmental Management Accounting (EMA);

3. perkiraan dampak dan biaya lingkungan eksternal, sering disebut dengan Full Cost Accounting (FCA);

Akuntansi lingkungan memberikan peran dalam tiga jenis perwujudan akuntansi, yaitu: Pertama, akuntansi keuangan, dalam hal ini akuntansi lingkungan berperan untuk memberikan tambahan informasi yang diungkapkan secara penuh (full disclosure) dan wajar atau dalam data kuantitatif pada laporan keuangan yang menunjukkan kegiatan dan hasil operasional perusahaan yang mencakup dimensi ekonomi, sosial, dan lingkungan. Kedua, akuntansi biaya, akuntansi lingkungan digunakan untuk alokasi biaya yang wajar dan pengendalian segala aktivitas perusahaan.Ketiga, akuntansi manjemen, akuntansi lingkungan berperan dalam pembuatan dan pengambilan keputusan manajemen maupun aspek pengendalian (Adnyana, Atmadja, Herawati, 2017).

Sedangkan menurut pendekatan kerangka akuntansi Triple bottom line accounting, pelaporan akuntansi meliputi aspek lingkungan, sosial dan keuangan. Konsep ketiga aspek tersebut dapat digambarkan pada gambar 1 sebagai berikut:

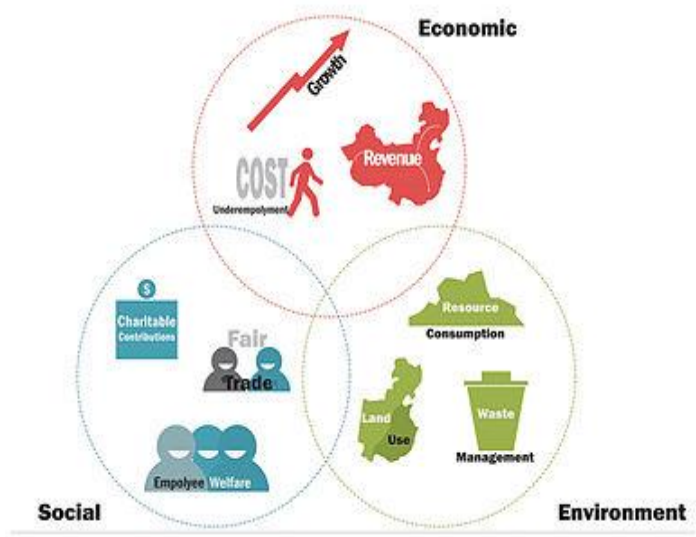

Gambar 1. Kerangka Akuntansi dengan Pendekatan Triple bottom line accounting Sumber: International Guidance Document: Environmental Management Accounting (2005)

Berdasarkan pendekatan triple bottom line accounting tersebut, maka pelaporan akuntansi tidak hanya pada aspek keuangan saja, akan tetapi meliputi aspek non keuangan yaitu aspek sosial sebagai bentuk pertanggungjawaban untuk menjalankan proses bisnis baik dan aspek lingkungan sebagai pertanggungjawaban potensi timbulnya dampak terhadap lingkungan atas pelaksanaan proses bisnis. Pada perkembangannya, konsep akuntansi lingkungan (environment accounting) berkembang menjadi green accounting, 
dalam konsep green accounting ini lingkupnya menjadi lebih luas tidak hanya pada aspek penyajian (pertanggungjawaban) dan pengungkapan biaya yang memiliki dampak pada lingkungan, tapi juga meliputi satu siklus akuntansi yang berpotensi berdampak pada lingkungan.

\section{International Financial Reporting} Standard (IFRS) mewajibkan adanya pengungkapan tidak hanya aspek finansial saja tetapi meliputi juga aspek non finansial.Sehingga, selain perusahaan menginformasikan informasinya kepada investor, perusahaan juga dituntut untuk dapat memberikan informasi tentang pengaruh perusahaan terhadap sumber daya yang ada di perusahaan maupun dari segi lingkungan dan sosial yang melibatkan perusahaan.Hal ini untuk mengantisipasi adanya kerugian finansial yang berasal dari kegiatan non finansial seperti pencemarah lingkungan, konflik sosial dan sebagainya.kerugian dari tindakan non finansial. Hal-hal seperti inilah yang saat ini juga diwajibkan oleh IFRS diungkapkan dalam laporan keuangan.

\section{Keberadaan BUM Desa}

Berdasarkan Peraturan Menteri Dalam Negeri Nomor 39 tahun 2010 tentang
Badan Usaha Milik Desa (BUMDes), dinyatakan bahwa BUMDes adalah suatu usaha desa yang dibentuk/didirikan oleh pemerintah desa yang kepemilikanmodal dan pengelolaannya dilakukan oleh pemerintah desa dan masyarakat (Permendagri 39/2010). Pembentukan BUMDes telah diatur dengan peraturan perundangan, yaitu UU No. 6/2014 tentang Desa, pasal 87, 88, 89 dan 90. Pasal 87 Ayat (1) Desa dapat mendirikan Badan Usaha Milik Desa yang disebut BUM Desa, (2) BUM Desa dikelola dengan semangat kekeluargaan dan kegotongroyongan, (3) BUM Desa dapat menjalankan usaha di bidang ekonomi dan/atau pelayanan umum sesuai dengan ketentuan peraturan perundang-undangan. Pasal 88 ayat (1) Pendirian BUM Desa disepakati melalui Musyawarah Desa, (2) Pendirian BUM Desa sebagaimana dimaksud pada ayat (1) ditetapkan dengan Peraturan Desa.

Pasal 89 mengaturhasil usaha BUM Desa dimanfaatkan untuk(a) pengembangan usaha; (b)Pembangunan Desa, pemberdayaan masyarakat Desa, dan pemberian bantuan untuk masyarakat miskin melalui hibah, bantuan sosial, dan kegiatan dana bergulir yang ditetapkan 
dalam Anggaran Pendapatan dan Belanja Desa.Pasal 90 menyebutkan bahwa Pemerintah, Pemerintah Daerah Provinsi, Pemerintah Daerah Kabupaten/Kota, dan Pemerintah Desa mendorong perkembangan BUM Desa dengan a.memberikan hibah dan/atau akses permodalan; b.melakukan pendampingan teknis dan akses ke pasar; dan c.memprioritaskan BUM Desa dalam pengelolaan sumber daya alam di Desa.

Sementara itu penjelasan pasal 87 ayat (1) UU No. 6/2014 tentang Desa menyebutkan BUM Desa dibentuk oleh Pemerintah Desa untuk mendayagunakan segala potensi ekonomi, kelembagaan perekonomian, serta potensi sumber daya alam dan sumber daya manusia dalam rangka meningkatkan kesejahteraan masyarakat Desa.BUM Desa secara spesifik tidak dapat disamakan dengan badan hukum seperti perseroan terbatas, $\mathrm{CV}$, atau koperasi.BUM Desa juga dapat melaksanakan fungsi pelayanan jasa, perdagangan, dan pengembangan ekonomi lainnya.Tujuan Pendirian BUM Desa di sini diarahkan sebagai badan di tingkat desa yang menyediakan jasa dan produk untuk memenuhi kebutuhan warga desa. Badan ini dituntut menjalankan fungsi ekonomi dan sosial, tidak mengejar keuntungan semata tetapi juga tidak boleh merugi agar usaha BUM Desa dapat berkelanjutan.

\section{Akuntansi Lingkungan, Green Accounting dan BUM Desa}

Merujuk pada tujuan pendirian BUMDes yang diarahkan sebagai badan di tingkat desa yang menyediakan jasa dan produk untuk memenuhi kebutuhan warga desa. Badan ini dituntut menjalankan fungsi ekonomi dan sosial. Peningkatan aspek ekonomi melalui unit usaha desa ini secara tidak langsung akan membawa konsekuensi dampak sosial. Pemanfaatan aset untuk disewakan, menjadi obyek wisata, atau pemberdayaan masyarakat untuk membentuk industri-industri rumahan yang dikoordinasikan di tingkat desa akan menimbulkan permasalahan lingkungan.

Akuntansi lingkungan pada BUMDes akan mengidentifikasi konsep akuntansi secara menyeluruh satu siklus akuntansi, mulai dari proses identifikasi, pengakuan, pengukuran, penyajian dan terakhir pengungkapan. Akun yang difokuskan adalah baik biaya maupun pendapatan yang berkaitan dengan lingkungan dan sosial.Pembahasan akan melihat dari aspek 
akuntansi keuangan, akuntansi biaya dan akuntansi manajemen.

Perwujudan dari penerapan akuntansi lingkungan pada akhirnya akan membentuk sebuah konsep green accountingyang bersifat holistik dalam satu siklus akuntansi baik aspek finansial maupun non finansial.

\section{Penelitian Terdahulu}

a. Akuntansi lingkungan dan Triple bottom line accounting

Suartana (2010) melakukan penelitian mengenai konsep green accounting dalam pendekatan triple bottom line accounting.Berdasarkan pendekatan tersebut, pelaporan entitas tidak hanya dari aspek finansial tetapi juga dari aspek lingkungan dan sosial.Green accountingakan mewujudkan laporan keuangan yang komprehensif dari suatu entitas. Laporan yang komprehensif akan sangat bermanfaat bagi stake holderdalam menilai kinerja suatu entitas. Implementasi green accountingserta pertanggungjawaban sosial suatu organisasi tetap mebutuhkan adanya evaluasi dan montoring yang bersifat periodik dan terstruktur berupa audit lingkungan yang merupakan bagian dari audit suatu entitas.

b. Tanggung jawab penerapan green accounting

Terdapat tanggung jawab yang berbeda bagi perusahaan dengan skala industri besar dan kecil.Musyaroh (2013) melakukan penelitian kuantitatif untuk mencari perbedaan tanggung jawab antara perusahaan dengan skala industri besar dan kecil.Semakin besar skala industri perusahaan, maka semakin besar pula tanggung jawab terhadap penerapan green accounting. Perbedaan tanggung jawab ini berdampak juga terhadap laporan keuangan dan audit yang berbeda pula.

c. Green accounting sebagai refleksi dari Corporate Social Responsibility (CSR) dan akuntansi lingkungan

Cho dan Patten (2013) melakukan penelitian bahwa pelaporan akuntansi saat ini tidak cukup hanya dari aspek keuangan saja, tetapi aspek-aspek non keuangan juga dapat terefleksikan di laporan keuangan.Oleh karena itu, pengungkapan aspek-aspek non keuangan bukan lagi menjadi suatu hal yang voluntary, tetapi menjadi hal 
yang mandatory untuk dilaksanakan oleh setiap entitas.

d. Adnyana, Atmadja, Herawati (2017) dalam Penerapan Akuntansi Lingkunganpada BUMDes Tajun, Bali melakukan penelitian dengan hasil BUMDes Desa Tajun khususnya dalam unit TPST tidak menyajikan biaya lingkungan secara spesifik pada laporan keuangannya. Biaya-biaya lingkungan yang terjadi dimasukan dalam rekening serumpun dalam laporan aktivitas operasi yaitu dalam biaya operasional.Maka dari itu, BUMDes Desa Tajun dapat dikatakan menerapkan model normatif dalam pengakuan biaya lingkungan dalam penyusunan laporan keuangannya.

\section{METODE PENELITIAN}

\section{a. Data}

Penelitian ini adalah penelitian yang bersifat kualitatif deskriptif.Dalam penelitian ini terdapat dua jenis data yang dipergunakan, yakni data kuantitatif dan data kualitatif. Data kuantitatif berhubungan dengan angka, atau jumlahyang terdapat dalam laporan keuangan BUMDes. Sedangkan data kualitatif yaitu berupa profil BUMDes, struktur organisasi,dan informasi yang diperoleh daripihak-pihak yang terkait.

\section{b. Teknik Pengumpulan Data}

Dalampenelitian ini menggunakan tigateknik pengumpulan data, yakniwawancara, observasi, danstudi dokumentasi.

1) Metode Wawancarayang digunakan dalam penelitian ini adalahwawancara mendalam, agar wawancara mendalam bisa berlangsung secara terarah, disusun pedoman wawancara yang memuat pokok-pokok pikiran yang terkaitdengan masalah yangditeliti. Penentuan informan difokuskan pada informan kunci yaitu Kepala Desa, Kepala BUMDes dan Bagian keuangan BUMDes.

2) Observasi, yaitu dengan melakukan pengamatan langsung mengenai proses bisnis yang dijalankan di BUM Desa khususnya yang terkait dengan penerapan green accounting .

3) Studi Dokumentasi, yaitu dengan mengumpulkan perencanaan kegiatan BUM Desa, catatan-catatan akuntansi terkait laporan keuanganBUM Desa dan 
dokumentasi terkait lainnya yang relevan seperti referensi.

\section{c. Teknik Analisis Data}

Analisis dilakukan terhadap data berdasarkan logika induktif. Analisis akan bergerak dari sesuatu hal yang khusus atau spesifik, yaitu yang diperoleh di lapangan, ke arah suatu temuan yang bersifat umum, yang akan muncul melalui analisis data berdasarkan teori yang digunakan. Teknik analisis data ini menggunakan tahapan sebagai berikut:

1) Koleksi Data

Pada tahapan ini melakukan pengumpulan data dari data primer dan sekunder.Data Primer berasal dari hasil wawancara pada personelpersonel kunci yang meliputi aspek Karakteristik BUM Desa, Potensi dan Permasalahan Lingkungan, Perencanaan Jangka Panjang BUM Desa dan Sejarah BUM Desa.Sedangkan Data Sekunder berasal dari dokumen laporan keuangan, perencanaan kegiatan dan referensi pendukung analisis data.

2) Reduksi Data

Reduksi data dilakukan melalui analisis hasil data primer dan
sekunder.Hasil data primer direduksi yang berkaitan dengan rumusan permasalahan, kemudian dikaitkan dengan hasil dari analisis data sekunder.

3) Penyajian Data

Hasil reduksi data yang telah dilakukan di tahapan sebelumnya menjadi data dasar untuk menarik kesimpulan. Data yang telah melalui proses reduksi akan disajikan baik dalam bentuk angka maupun narasi deskriptif.

4) Kesimpulan dan saran

Tahapan akhir adalah menarik kesimpulan berdasarkan data yang telah disajikan, kemudian mengusulkan saran yang operasional untuk pengembangan jangka panjang baik bagi obyek penelitian maupun bagi peneliti berikutnya.

\section{HASIL DAN PEMBAHASAN}

Pembahasan atas penerapan akuntansi lingkungan pada BUMDes " $X$ " dilakukan dengan tahapan analisis yang digambarkan pada gambar 2. "TahapanAnalisis Penerapan Akuntansi Lingkungan" yang tersaji sebagai berikut: 


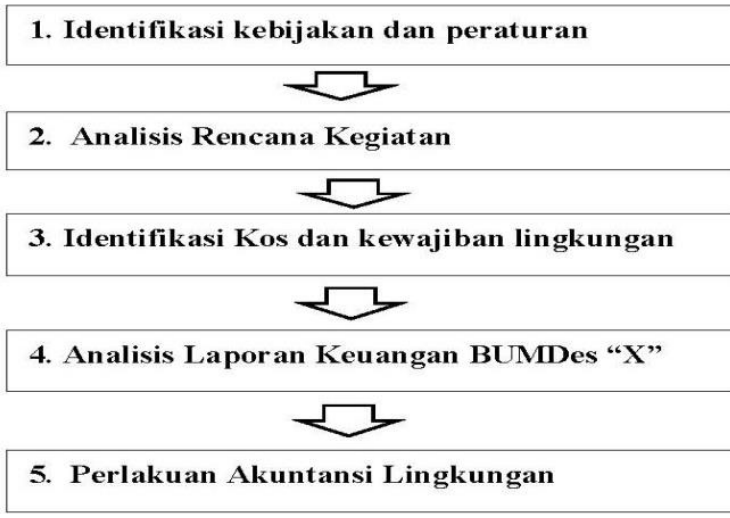

Gambar 2. Tahapan Analisis Penerapan Akuntansi Lingkungan

\section{a. Identifikasi Kebijakan dan Peraturan}

BUMDes " $X$ " adalah salah satu BUMDes yang berada di Kabupaten Kulon Progo Yogyakarta. Berkaitan dengan kebijakan dan peraturan mengenai lingkungan, Pemerintah Kabupaten Kulon Progo menuangkan dalam Rencana Pembangunan Jangka Menengah Daerah (RPJMD) Kabupaten Kulon Progo Tahun 2017-2022, bahwa "penyusunan RPJMD Kabupaten Kulon Progo Tahun 2017-2022 juga wajib untuk dilakukan Kajian Lingkungan Hidup Strategis (KLHS) sesuai amanat Undang-Undang Nomor 32 Tahun 2009 tentang Perlindungan dan Pengelolaan Lingkungan Hidup. Proses pembuatan dan pelaksanaan KLHS RPJMD sesuai Peraturan Pemerintah Nomor 46 Tahun
2016 tentang Tata Cara Penyelenggaraan Kajian Lingkungan Hidup Strategis melalui mekanisme antara lain pengkajian pengaruh kebijakan, rencana, dan / atau program terhadap kondisi lingkungan hidup". Permasalahan lingkungan yang sedang dihadapi adalah meningkatnya pertumbuhan produk sampah, baik sampah domestik maupun sampah non domestik.Upaya pengelolaan sampah dapat dilakukan dengan upaya reduksi sampah di sumber penghasil sampah, yaitu di lingkungan rumah tangga. Salah satu cara yang telah ditempuh adalah membentuk kelompok masyarakat pengolah sampah.

BUMDes "X" salah satu BUMDes yang menjalankan unit usaha pengolahan sampah yang dimulai Tahun 2017 untuk infrastruktur dan Tahun 2018 untuk operasional aktivitas pengolahan sampah. Aktivitas yang dilakukan adalah mengumpulkan sampah rumah tangga, instansi dan industri dengan menerapkan retribusi sebesar Rp20.000,- untuk rumah tangga dan Rp30.000,- untuk instansi dan industri per bulan. Sampah kemudian akan dibawa ke tempat penampungan dengan memilah menjadi sampah organik, plastik dan kaca. 
Standar Akuntansi Keuangan(SAK) yang diterbitkan oleh Ikatan Akuntan Indonesia (IAI) merupakan regulasi yang mengatur mengenai akuntansi keuanganyang terdiri daripernyataan standar akuntansi keuangan (PSAK) untuk mengatur lingkup akuntansi keuangan.Berkaitan dengan akuntansi dampak lingkungan dari aktivitas perusahaan dinyatakan pada PSAK No. 1 mengenai penyajian laporan keuangan paragraf 14bahwa "Beberapa entitas juga menyajikan, dari laporan keuangan, laporan mengenai lingkungan hidup dan laporan nilai tambah, khususnya bagi industri dimana faktor lingkunganhidupadalah signifikan”.

\section{b. Analisis Rencana Kegiatan}

Berdasarkan dokumen RPJMD, BUMDES " $\mathrm{X}$ " juga wajib menjalankan upaya pengelolaan lingkungan.Tahun 2017 telah dimulai program pengelolaan lingkungan dengan usulan pembangunan tempat penampungan dan pemilahan sampah.Sosialisasi kepada masyarakat desa telah dilakukan untuk memberikan edukasi kepada masyarakat terkait dengan kesadaran lingkungan pada Februari 2018.Upaya yang saat ini sedang dikelola dan direncanakan adalah reduksi sampah di sumber penghasil sampah, yaitu di lingkungan rumah tangga. Salah satu cara melakukan reduksi sampah di lingkungan rumah tangga adalah dengan membentuk kelompok masyarakat pengolah sampah. Pada Sampah plastik telah dilakukan pengolahan oleh kelompok pengrajin rumahan menjadi beberapa produk yang bernilai tambah. Sampah organik sedang dalam proses pengolahan menjadi pupuk kompos. Infrastuktur untuk pengolahan kompos ini telah dibangun dengan program hibah.Perencanaan selanjutnya adalah pengolahan terhadap limbah kaca untuk dapat diolah atau didaur ulang kembali untuk dapat bernilai tambah.

c. Identifikasi Kos atas Prasarana dan kewajiban lingkungan

1. Identifikasi Kosatas Prasarana

Berdasarkanhasil wawancara dan telaah dokumencatatan keuangan BUMDes " $\mathrm{X}$ " diperoleh beberapa prasaranayang berhubungan denganakuntansi lingkungan dan kos yang melekat pada prasarana tersebut. Terdapat prasarana yang merupakan bantuan yaitu berupa tempat penampungan dan pemilahan, sedangkan kendaraan pengangkut 
sampah merupakan pengadaan yang dilakukan oleh BUMDes "X". Adapun rincian sarana dan kos yang melekat pada sarana tersebut tersaji pada tabel 1.

Tabel 1. Daftar Sarana Pengolahan Limbah Organik dan Non-organik di BUMDes "X" per September 2018

\begin{tabular}{|c|c|c|c|}
\hline No & Sarana & $\begin{array}{l}\text { Kos/Harga } \\
\text { Perolehan }\end{array}$ & Fungsi \\
\hline 1 & $\begin{array}{l}\text { Tempat } \\
\text { Penampungan } \\
\text { dan } \\
\text { Pemilahan }\end{array}$ & Bantuan & $\begin{array}{l}\text { Penampungan } \\
\text { sampah yang } \\
\text { telah } \\
\text { direduksi dari } \\
\text { rumah } \\
\text { tangga, } \\
\text { instansi dan } \\
\text { industri }\end{array}$ \\
\hline 2 & $\begin{array}{l}\text { Kendaraan } \\
\text { Pengangkut } \\
\text { Sampah }\end{array}$ & Rp12.400.000,- & $\begin{array}{l}\text { Operasional } \\
\text { Pengangkutan } \\
\text { Sampah }\end{array}$ \\
\hline
\end{tabular}

Sumber: Data Hasil Wawancara dan telaah dokumen

2. Kewajiban Lingkungan

Kewajiban untuk membayar pengeluaran masa depan untuk memperbaiki kerusakan lingkungan yang telah terjadi karena peristiwa, kegiatan atau transaksi masa lalu atau untuk mengkompensasi pihak ketiga yang menderita kerusakan, termasuk tanggung jawab lingkungan kontinjensi yang tergantung pada kejadian atau tidak terjadinya satu atau lebih peristiwa masa depan yang tidak pasti atau untuk mengkompensasi pihak ketiga yang telah menderita kerusakan tersebut (Sunitha, 2015).Atas kewajiban ini, BUMDes "X" belum mengalokasikan pengeluaran dengan pertimbangan program pengelolaan lingkungan ini baru dimulai di tahun 2018.Sehingga pengeluaran yang saat ini dilakukan adalah memenuhi sarana dan prasarana dasar.

d. Analisis Laporan Keuangan

\section{BUMDes"X"}

Berdasarkan analisa terhadap laporan keuangan BUMDes " $\mathrm{X}$ " ini, didapati bahwa BUMDes " $\mathrm{X}$ " membuat beberapa laporan keuangan sesuai dengan jenis usaha yang ada meliputi simpan pinjam, penyewaan mesin molen, usaha fotokopi, pengelolaan sampah dan BUMDes itu sendiri. Berkaitan dengan pengelolaan sampah ini BUMDes " $X$ " belum membuat laporan keuangan secara lengkap, seperti laporan neraca, buku besar, jurnal, arus kas, dan laporan terkait lainnya.Namun, BUMDes " $X$ " hanya membuat sejumlah laporan keuangan yang sederhana dan ringkas dalam bentuk laporan penerimaan dan 
pengeluaran kas yang disajikan pada tabel 2. Berdasarkan Tabel 2 tersebut, BUMDes "X" baru melakukan transaksi dengan memisahkan catatan untuk unit usaha pengelolaan sampah di Bulan Agustus 2018 dengan memperoleh dukungan kas sebesar Rp1.000.000,Sedangkan kegiatan sebelumnya berupa sosialisasi edukasi kesadaran lingkungan sebesar Rp550.000,- menggunakan kas dari BUMDes begitu pula pembelian kendaraan pengangkut sampah sebesar Rp12.400.000,- menggunakan kas BUMDes. Sehingga pencatatan yang terdapat di unit usaha pengelolaan sampah tidak termasuk pengeluaran tersebut. Sedangkan pemasukan yang saat ini diperoleh adalah bersumber dari retribusi sampah yang dikenakan kepada rumah tangga, instansi dan industri yang bersedia bekerja sama. Besaran retribusi ini Rp20.000,- untuk rumah tangga dan Rp30.000,- untuk instansi dan industri. BUMDes " $X$ " melakukan pencataatn sesuai dengan transaksi yang terjadi. Meskipun pencatatannya masih sederhana, akan tetapi penyajian terpisah laporan pengelolaan sampah ini telah menunjukkan kepedulian BUMDes " $X$ " dalam memberikan informasi terkait dengan pengelolaan lingkungan.

Tabel 2. Catatan Kas Unit Usaha

Pengelolaan Sampah

\begin{tabular}{|c|c|c|c|c|}
\hline Tanggal & Keterangan & Kas Masuk & Kas Keluar & Saldo \\
\hline $1 \mid \operatorname{Ags}$ & Penyertaan kas dari kas BUMDes & $1,000,000$ & & $1,000,000$ \\
\hline 1 Ags & Beli bensin viar & & 35,000 & 965,000 \\
\hline \begin{tabular}{l|l}
1 & Ags \\
\end{tabular} & Retribusi Sampah bulan Agustus & 610,000 & & $1,575,000$ \\
\hline 1 Sept & Ganti Laker viar & & 47,000 & $1,528,000$ \\
\hline 1|Sept & Beli Remover kecil & & 20,000 & $1,508,000$ \\
\hline 1 Sept & Beli BBM & & 50,000 & $1,458,000$ \\
\hline $3 \mid$ Sept & Bayar petugas pengambil sampah bln agts & & 180,000 & $1,278,000$ \\
\hline $21 \mid$ Sept & belibbm & & 25,000 & $1,253,000$ \\
\hline
\end{tabular}

Sumber: Data diolah

Berdasarkan laporan yang disusun oleh BUMDes "X" tersebut, maka format pelaporan akuntansi lingkungan yang digunakan adalah Outlay Cost Approach, yaitu pelaporan akuntansi dengan cara mengungkapkan berapa cost yang dikeluarkan oleh perusahaan sehubungandengan pertanggungjawaban sosial yang dilakukannya degan membagi ke dalam kategori tertentu (Parker, Ferris dan Otley (Purwono, 2000)).

\section{e. PerlakuanAkuntansi Lingkungan}

1. Akuntansi lingkungan dilihat dari segi pengguna

Akuntansi lingkungan dapat dibedakan dari segi pengguna menjadi akuntansi keuangan, akuntansi manajemen dan 
akuntansi biaya (Kusumaningtyas, 2013). Pembahasan yang terdapat di BUMDes " $X$ " berkaitan dengan hal ini adalah sebagai berikut:

1) Akuntansi Keuangan

Akuntansi lingkungan dari konteks akuntansi keuangan merujuk pada sebuah proses pertanggungjawaban kepada pengguna eksternal dalam rangka mewujudkan akuntabilitas pelaporan lingkungan. Pelaporan akuntabilitas lingkungan ini menyesuaikan dengan prinsip akuntansi berterima umum.Pada BUMDes " $\mathrm{X}$ " akuntansi lingkungan dari sisi pengguna eksternal terwujud dalam adanya catatan yang khusus digunakan untuk pengelolaan sampah, terpisah dari transaksi BUMDes yang lainnya. Meskipun penyajian pada catatan tersebut masih sederhana berupa kas masuk dan kas keluar, akan tetapi sudah memenuhi akuntabilitas kepada pengguna eksternal untuk memberikan informasi mengenai aktivitas pengelolaan sampah.

2) Akuntansi Manajemen
Akuntansi lingkungan dari konteks akuntansi manajemen merujuk pada sebuah proses pengambilan keputusan oleh manajemen atau pihak internal entitas, baik keputusan mengenai pertimbangan investasi, permodalan, evaluasi kinerja maupun pengembangan program yang berkaitan dengan lingkungan. Pada BUMDes " $\mathrm{X}$ " akuntansi lingkungan dari sisi pengguna internal dalam pengambilan keputusan sudah terlihat dengan akan dikembangkannya pengolahan sampah organik menjadi pupuk kompos, pengolahan sampah plastik yang dikelola oleh kelompok wanita tani menjadi produk-produk bernilai tambah, serta ke depannya akan dikembangkan pengolahan limbah kaca untuk dapat bernilai tambah.

3) Akuntansi Biaya

Akuntansi biaya dalam konteks akuntansi biaya mengacu pada proses penentuan biaya yang akan dipertanggungjawabkan 
oleh manajemen atas proses bisnis yang dijalankan. Pada BUMDes "X" akuntansi lingkungan dari sisi pertanggungjawaban biaya dapat terlihat pada penentuan besaran tarif retribusi dan penentuan biaya yang dikeluarkan dalam program pengelolaan lingkungan ini.

2. Identifikasi, Pengakuan, Pengukuran, Penyajian dan Pengungkapan

Konsep akuntansi lingkungan sebagai upaya mengungkapkan biaya-biaya lingkungan yang terjadi dalam sebuah entitas pada dasarnya merujuk konsep akuntansi pada umumnya, sesuai dengan kerangka konseptual pelaporan keuangan, proses pembentukan pos-pos dalam laporan keuangan akan meliputi proses identifikasi, pengakuan, pengukuran, penyajian dan yang terakhir pengungkapan.

1) Identifikasi

Identifikasi di sini adalah proses identifikasi biaya-biaya atau pendapatan yang berkaitan dengan pengelolaan lingkungan. Pada BUMDes " $X$ " identifikasi biaya meliputi biaya pemeliharaan kendaraan pengangkut sampah, tenaga kerja pengangkut sampah, sedangkan pendapatan diperoleh dari retrubusi pengangkutan sampah dari rumah tangga, instansi dan industri. Biaya-biaya yang teridentifikasi sebagai biaya lingkungan pada BUMDes " $X$ " teridentifikasi sebesar Rp978.000. Sedangkan pendapatan lingkungan yang teridentifikasi sebagai pendapatan lingkungan sebesar Rp610.000,-

2) Pengakuan

Pengakuan dalam hal ini adalah saat sebuah transaksi memenuhi unsur dan kriteria pengakuan yang akan dinyatakan dalam kata-kata atau jumlah moneter dan mencantumkannya pada laporan keuangan. Pada BUMDes "X" biaya-biaya yang terjadi diakui pada saat biaya tersebut terjadi begitu pula terkait pendapatan diakui pada saat kas dari retribusi telah diterima. Sehingga dapat dikatakan BUMDes " $X$ " menganut 
pengakuan cash basis atau mengakui biaya dan pendapatan saat kas benar-benar sudah keluar dan masuk.

3) Pengukuran

Kerangka Dasar Penyusunan Laporan Keuangan menyatakan bahwa pengukuran adalah proses penetapan jumlahmoneter ketikaunsur-unsur laporan keuanganakan diakui dan dicatat dalam laporan keuangan. BUMDes " $X "$ mengukur dan menilai biaya yang dikeluarkan menggunakan satuan moneter rupiah sesuai dengan jumlah saat transaksi terjadi.Begitu pula dengan pendapatan diukur dan dinilai menggunakan satuan moneter rupiah sesuai dengan jumlah saat transaksi terjadi.

4) Penyajian

BUMDes " $\mathrm{X}$ " telah menyajikan secara terpisah laporan berkaitan dengan pengelolaan sampah. Meskipun format laporan masih sederhana berupa kas masuk, kas keluar serta catatan sarana, akan tetapi telah terinformasi kepada pembaca laporan bahwa terdapat penyajian khusus berkaitan dengan akuntansi lingkungan.

5) Pengungkapan

PSAK 1 penyajian laporan keuanganmenyatakan bahwa pengungkapan dilakukan untuk membantupengguna laporan keuangan untuk memahami bagaimana transaksi, peristiwa dan kondisi lain tercermin dalam laporan kinerja keuangan yang dilaporkan. Berkaitan dengan pengungkapan ini, dikarenakan bentuk laporan pengelolaan sampah berupa kas masuk dan kas keluar, maka pada laporan tersebut tidak terlihat pengungkapan yang sesuai PSAK disajikandi catatan atas laporan keuangan.Akan tetapi, BUMDes "X" menyusun laporan kinerja tahunan yang memuat informasiinformasi berkaitan dengan kinerja yang telah dilaksanakan.Termasuk dalam laporan kinerja tersebut pengelolaan sampah yang menjadi salah satu unit usaha BUMDes. 


\section{SIMPULAN}

Berdasarkan hasil pembahasan penelitian, BUMDes "X" memiliki unit usaha pengelolaan sampah yang sedang dalam tahap awal pengembangan.Secara regulasi atau kebijakan, BUMDes "X" telah menjalankan yang diamanahkan RPJMD untuk melakukan usaha pengelolaan limbah.Selain itu, sesuai dengan PSAK 1 tentang penyajian pelaporan keuangan, BUMDes " $X$ " telah menyusun laporan yang berkaitan dengan dampak lingkungan.Meskipun pencatatannya masih sederhana, akan tetapi penyajian terpisah laporan pengelolaan sampah ini telah menunjukkan kepedulian BUMDes " $\mathrm{X}$ " dalam memberikan informasi terkait dengan pengelolaan lingkungan. BUMDes "X" telah memenuhi kaidah identifikasi, pengakuan, pengukuran dan penyajian akuntansi lingkungan.Terkait dengan pengungkapan, belum dilakukan dalam bentuk catatan atas laporan keuangan, tetapi pada laporan kinerja BUMDes.Secara konsep, akuntansi lingkungan telah menjadi kepedulian sampai di tingkat pemerintah daerah, yaitu dengan dimasukkannya pada RPJMD.Akan tetapi, secara istilah akuntansi lingkungan belum terlalu
dipahami.Optimalisasi

penerapan akuntansi lingkungan pada akhirnya tergantung pada kebijakan, sumber daya manusia, dan kesiapan infrastruktur dari entitas yang melaksanakan.Pembahasan yang mendalam di tingkat pembuat kebijakan menjadi salah satu kunci keberhasilan dalam penerapan akuntansi lingkungan.

\section{DAFTAR PUSTAKA}

Adnyana, Atmadja, Herawati, 2017, “Analisis Penerapan Akuntansi Lingkungan Pada Badan Usaha Milik Desa Untuk Mewujudkan Green Accounting (Studi Pada Bumdes Desa Tajun, Kecamatan Kubutambahan, Kabupaten Buleleng, Provinsi Bali)", e-Journal Universitas Pendidikan Ganesha Jurusan Akuntansi Program S1 (Vol: 8 No: 2 Tahun 2017)

Cho, Charles H; Patten, Dennis M, 2013, "Green accounting: Reflections from a CSR and environmental Disclosure perspective", Elsevier, issue May.

Committee on Incorporating Sustainability in the U.S. Environmental Protection Agency;National Research Council, 2011, "Sustainability and the U.S. EPA”, USA. 
Government of Japan, 2012, Ministry of the Environment Government of Japan, Environmental Reporting Guidelines, April 2012.

Ikatan Akuntan Indonesia, 2017, Standar Akuntansi Keuangan, Jakarta.

International Federation Accountans,

International Guidance Document, Pemerintah Republik Indonesia, 2014, 2005, "Environmental Management Accounting".

Kusumaningtyas, 2013, “Green Accounting,

Mengapa

Dan

Bagaimana?",Proceeding Seminar

Nasional, ISBN: 978-979-636-147-2,

Surakarta.

Musyarofah, Siti, 2013, “Analisis Penerapan

Green Accounting Di Kota Semarang”, Accounting Analysis Journal.

Pemerintah Republik Indonesia, 2010,Peraturan Menteri Dalam Negeri Nomor 39 Tahun 2010 Tentang Badan Usaha Milik Desa.

Pemerintah Republik Indonesia, 2015,Peraturan Menteri Desa

Pembangunan Daerah Tertinggal dan

Transmigrasi Nomor 4 Tahun 2015

Tentang Badan Usaha Milik Desa.

Pemerintah Republik Indonesia, 2017,

Peraturan Pemerintah Republik

Indonesia Nomor 46 Tahun 2017
Tentang Instrumen Ekonomi Lingkungan Hidup.

Pemerintah Kabupaten Kulonprogo, 2017, Peraturan Daerah Rencana Pembangunan Jangka Menengah Daerah Kabupaten Kulon Progo Tahun 2017-2022 Undang-Undang Republik Indonesia Nomor 6 Tahun 2014 tentang Desa. 
Jurnal MONEX Volume 8 Nomor. 1 Januari 2019

p-ISSN: 2089-6778

e-ISSN: 2549-5054 